\title{
Overexpression of EGFR as an Independent Prognostic Factor in Adenocarcinoma of the Esophagogastric Junction
}

\author{
KENICHI ARATANI $^{1 *}$, SHUHEI KOMATSU ${ }^{1 *}$, DAISUKE ICHIKAWA ${ }^{1}$, TAKUMA OHASHI ${ }^{1}$, \\ MAHITO MIYAMAE ${ }^{1}$, WATARU OKAJIMA ${ }^{1}$, TAISUKE IMAMURA ${ }^{1}$, JUN KIUCHI ${ }^{1}$, \\ KEIJI NISHIBEPPU ${ }^{1}$, TOSHIYUKI KOSUGA ${ }^{1}$, HIROTAKA KONISHI ${ }^{1}$, ATSUSHI SHIOZAKI ${ }^{1}$, \\ HITOSHI FUJIWARA ${ }^{1}$, KAZUMA OKAMOTO $^{1}$, HITOSHI TSUDA $^{2,3}$ and EIGO OTSUJI ${ }^{1}$ \\ ${ }^{1}$ Division of Digestive Surgery, Department of Surgery, \\ Kyoto Prefectural University of Medicine, Kyoto, Japan; \\ ${ }^{2}$ Department of Pathology, National Cancer Center Hospital, Tokyo, Japan; \\ ${ }^{3}$ Department of Basic Pathology, National Defense Medical College, Saitama, Japan
}

\begin{abstract}
Background: Adenocarcinoma of the esophagogastric junction (AEG) has increased in Western and Eastern countries, and its prognosis remains poor. We tested whether epidermal growth factor receptor (EGFR), that is overexpressed in various tumors, acts as a cancer-promoting gene through overexpression in AEG. Materials and Methods: We analyzed 104 primary AEG tumors which were curatively resected in our hospital between 2000 and 2010. Results: Overexpression of EGFR protein was detected in $47 \%$ primary AEG tumor samples, and significantly associated with venous and lymphatic invasion, tumor depth and lymph node metastasis. The high-expression group had a significantly poorer prognosis than the low expression group for overall and disease-free survival. EGFR positivity was independently associated with a worse outcome in the multivariate analysis ( $p=0.0397$, hazard ratio $(H R)=2.048)$. Conclusion: EGFR plays a pivotal role in AEG through its overexpression, which highlights its usefulness as a prognosticator and potential therapeutic target in AEG.
\end{abstract}

Over the past few decades, adenocarcinoma of the esophagogastric junction (AEG) has markedly increased in Western and Eastern countries (1-5). Despite the improvement

*These Authors contributed equally to this study.

Correspondence to: Shuhei Komatsu MD, Ph.D., Division of Digestive Surgery, Department of Surgery, Kyoto Prefectural University of Medicine, 465 Kajii-cho, Kawaramachihirokoji, Kamigyo-ku, Kyoto 602-8566, Japan. Tel: +81 752515527, Fax: +81 752515522, e-mail: skomatsu@koto.kpu-m.ac.jp

Key Words: Adenocarcinoma, esophagogastric junction, EGFR, prognosis, oncogene. of diagnosis and treatment technologies such as extended radical resection and chemo- or chemoradiotherapy, many patients with AEG frequently develop metastasis and experience recurrence, and long-term survival remains poor because of the aggressive and systemic nature of the disease (6).

The epidermal growth factor receptor family of receptors, also called the human epidermal growth factor receptor (HER) family of tyrosine kinases, include ERBB1 (EGFR), ERBB2 (HER2), ERBB3, and ERBB4, which are encoded by ERB oncogenes (7) and have been implicated in tumor cell growth and differentiation. All members share a common structure, with an extracellular ligand-binding domain, a transmembrane domain, and an intracytoplasmic tyrosine kinase domain. Ligand binding to these receptors induces the formation of receptor homodimers and heterodimers, and the activation of downstream signaling pathways. The HER family might, therefore, contribute to malignant progression.

Recently, trastuzumab, a monoclonal antibody against human epidermal growth factor receptor type 2 (HER2), was shown to improve response rate, progression-free survival (PFS), and overall survival (OS) when added to cisplatin based chemotherapy in patients with HER2 overexpressing AEG and gastric adenocarcinomas (8). However, HER2 overexpressing esophagogastric tumors are in the minority, and the need for additional targeted agents is urgent. Protein overexpression or gene amplification of EGFR has been reported in several human tumors of epithelial origin, including of head and neck (9-11), thyroid (12), breast (13, 14), ovarian (15), colon (16-19), cervix, bladder (20) and lung (21). In a subset of these tumors, most notably breast cancer, colorectal cancer, and esophageal squamous cell carcinoma $(22,23)$, increased EGFR expression has been associated with advanced disease, development of metastases, and poor prognosis. Regarding gastric cancer, 
several previous reports have identified the clinical and biological significance of EGFR overexpression (24-28). Specifically, Terashima et al. reported that EGFR overexpression is significantly associated with worse patient outcomes after curative gastrectomy for stage II/III gastric cancer (28). These findings prompted us to determine the clinicopathological and prognostic significance of EGFR overexpression/activation in primary AEG.

In this study, we tested whether EGFR acts as a cancerpromoting gene through its activation/overexpression in AEG. Our results provide evidence that EGFR could be an important molecular marker for determining the malignant properties of AEG and also a target for molecular therapy.

\section{Materials and Methods}

Primary AEG tissue samples. Primary tumor samples of AEG were obtained from 104 consecutive patients with AEG who had undergone curative resection at the Division of Digestive Surgery, Department of Surgery, Kyoto Prefectural University of Medicine (Kyoto, Japan) between 2000 and 2010. The samples were embedded in paraffin after $24 \mathrm{~h}$ of formalin fixation. Relevant clinical and survival data were available for all patients. Written consent was always obtained in the formal style and after approval by the local Ethics Committee. None of these patients underwent endoscopic mucosal resection, palliative resection, preoperative chemotherapy, or radiotherapy, and none of them had synchronous or metachronous multiple cancer in other organs. Disease stage was defined in accordance with the International Union Against Cancer Tumor-Lymph Node-Metastases (TNM) classification (seveth edition) (29). The mean follow-up period for surviving patients was 51.2 months.

Immunohistochemistry. The protein expression of EGFR was quantified by immunohistochemical analysis. The tissues were reacted with primary antibody EGFR(sc-03), which was purchased from Santa Cruz Biotechnology (Dallas, TX, USA). Primary tumor samples were fixed with $10 \%$ formaldehyde in phosphate-buffered saline (PBS) and routinely embedded in paraffin. Horseradish peroxidase (HRP) staining method was used. In brief, after deparaffinization, antigen retrieval was performed by heating the samples in $10 \mathrm{mmol} / 1$ citrate buffer $(\mathrm{pH} 6.0)$ at $95^{\circ} \mathrm{C}$ for $60 \mathrm{~min}$. Endogenous peroxidases were quenched by incubating the sections for $20 \mathrm{~min}$ in $3 \% \mathrm{H}_{2} \mathrm{O}_{2}$. After treatment with Block Ace (Dainippon Sumitomo Pharmaceutical, Osaka, Japan) for $30 \mathrm{~min}$ at room temperature, sections were incubated overnight at $4^{\circ} \mathrm{C}$ with an antiEGFR (1:500). PBS was used for all dilutions and washings. Bound primary antibody was detected with EnVision ${ }^{\mathrm{TM}}+$ Horse Radish Peroxidase Systems (EnVision + dual link System-HRP; Dako North America, Inc., Carpinteria, CA, USA). HRP labeling was visualized using color development with diaminobenzidine tetrahydrochloride. Slides were counterstained with Mayer's hematoxylin.

To evaluate EGFR expression, primary tumors were judged positive if at least $10 \%$ or more of the total cell population showed EGFR immunopositivity and negative if fewer than $10 \%$ showed EGFR immunopositivity. For the intensity of EGFR expression, the intensity score $(0=$ negative, $1=$ weak, $2=$ moderate, $3=$ strong $)$ was recorded. Namely, primary tumors with non-detectable EGFR expression, that were similar to non-tumorous gastric mucosa and stroma, were given an intensity score of 0 , whereas those with the greatest EGFR abundance were given an intensity score of 3 . The remaining tumors were categorized with intensity scores of 1 or 2 according to the intensity of immunohistochemical staining for EGFR. The expression of EGFR was regarded as high expression for both an intensity score of 3 and $\geq 10 \%$ of tumor cells showing immunopositivity, or low expression for an intensity score of or less 2 or $<10 \%$ using high-powered $(\times 200)$ microscopy $(30,31)$.

Statistical analysis. Clinicopathological variables pertaining to the corresponding patients were analyzed for statistical significance using the Chi-squared test or Fisher's exact test. For the analysis of survival, Kaplan-Meier survival curves were constructed for groups based on univariate predictors, and differences between the groups were analyzed with the log-rank test (Figure 1B and C). Univariate and multivariate survival analyses were performed using the likelihood ratio test of the stratified Cox proportional hazards model. The data were stratified for multivariate analysis using both forward and backward stepwise Cox regression procedures. Differences were assessed with a two-sided test and were considered statistically significant at $p<0.05$.

\section{Results}

Clinicopathological characteristics of patients with AEG. The clinical characteristics in 104 consecutive patients with AEG were as follows. Of 104 patients, 12 patients were defined as having tumor Siewert type I, 60 patients as Siewert type II and 32 patients as Siewert type III based on the tumor location. The study group consisted of 82 male and 22 female patients, with a median age of 66 years (range $=28-85$ years). Of 104 patients, 37 had disease staged as pStage I, 17 as pStage II, and 50 as pStage III.

Immunohistochemical analysis of EGFR expression in primary AEG tumors. The clinicopathological significance of EGFR expression in primary tumor samples of AEG based on the immunohistochemical staining pattern of this protein was examined. EGFR expression was detected in the surface membrane of AEG cells. We classified 104 AEG tumors into positive and negative groups according to the intensity of EGFR staining of tumor cells as described in the Materials and Methods Section. In primary cases, normal esophageal squamous mucosa show complete membranous staining EGFR. In contrast, the nonneoplastic gastric mucosa show no EGFR immunoreactivity. The underlying cardiac glands show incomplete membranous staining. We divided 104 AEG tumors into a high expression group $(\mathrm{n}=49,47 \%)$ and a low expression group $(\mathrm{n}=55,53 \%)$ according to the intensity of EGFR staining of tumor cells (Figure 1A). The high-expression group had a significantly poorer prognosis than the low expression group for overall survival $(p=0.0035$, log-rank test; Figure 1B) and disease-free survival ( $p=0.015, \log$-rank test; Figure 1C). 


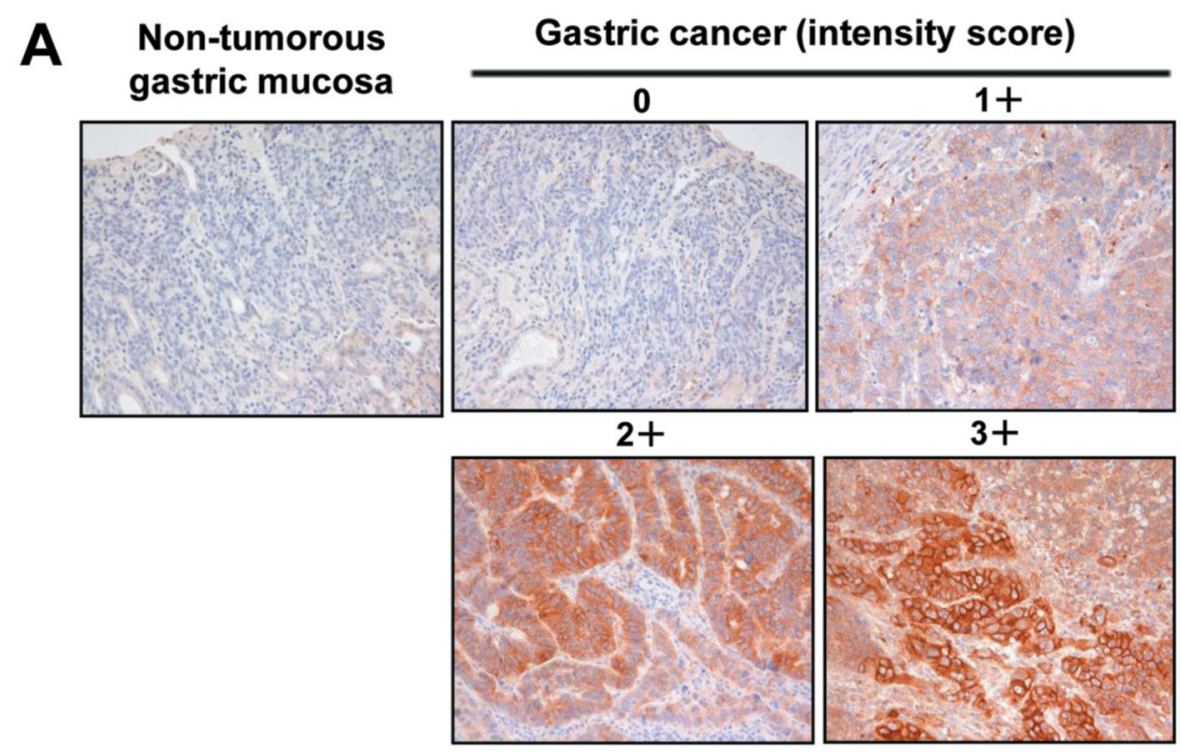

B
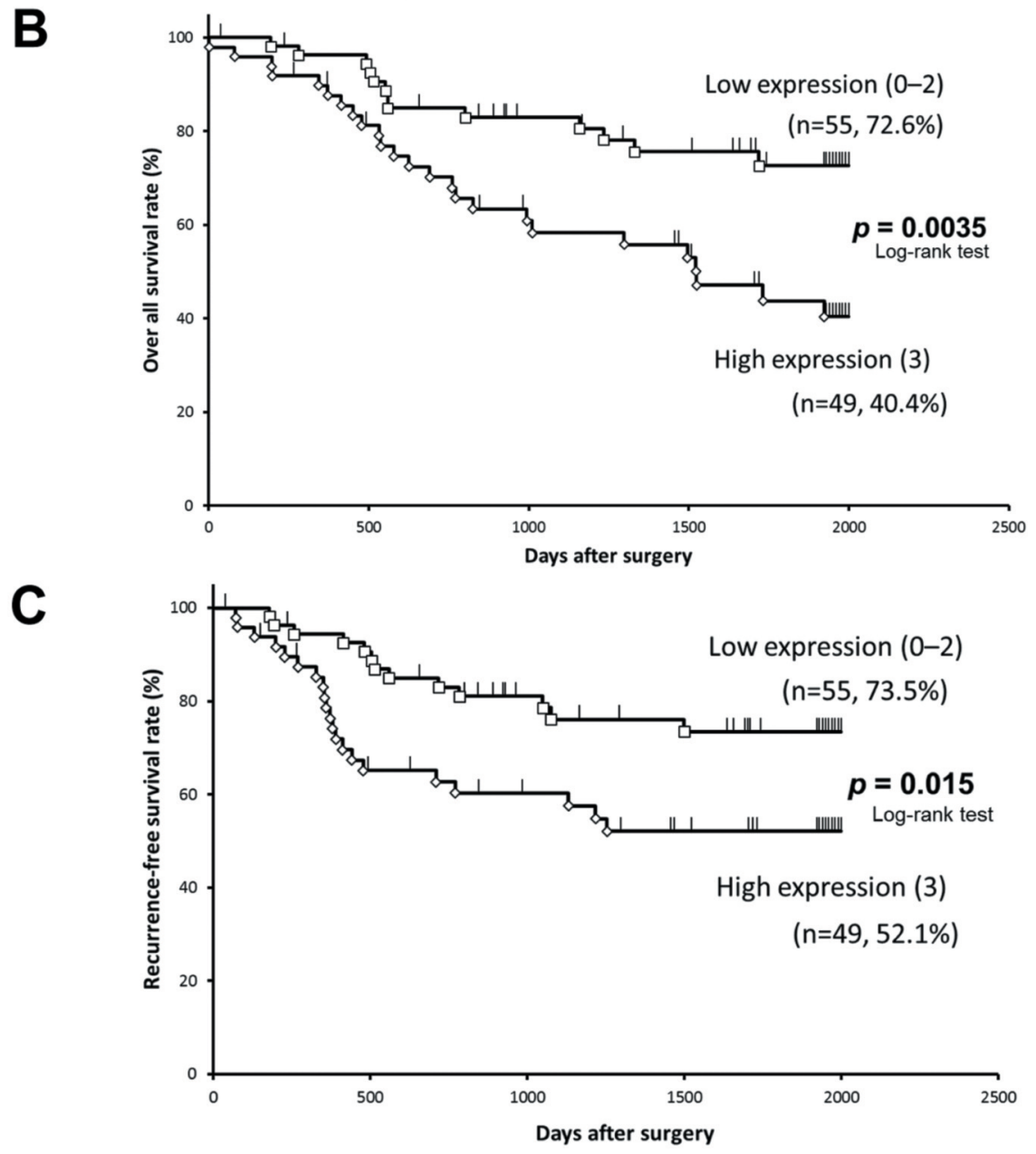

Figure 1. Immunohistochemical-staining analyses and postoperative overall and disease-free survival curves according to the expression of epidermal growth factor receptor (EGFR). A: Specific immunostaining of the EGFR protein in primary samples was confirmed. Expression of EGFR protein was observed in the cytoplasm of cancer cells. For scoring of EGFR expression, the intensity score was defined as $0=n e g a t i v e, 1=w e a k, 2=m o d e r a t e$, $3=$ strong. B, C: The group with high EGFR expression had a significantly poorer prognosis than that with low expression in both overall ( $p<0.0001$, log-rank test) and recurrence-free ( $p=0.0013$, log-rank test) survival. 
Table I. Association between clinicopathological characteristics and epidermal growth factor receptor (EGFR) expression.

\begin{tabular}{|c|c|c|c|c|}
\hline & \multirow[b]{2}{*}{$\mathrm{n}$} & \multicolumn{2}{|c|}{ EGFR immunoreactivity, n (\%) } & \multirow[t]{2}{*}{$p$-Value* } \\
\hline & & High & Low & \\
\hline Total & 104 & 49 & 55 & \\
\hline \multicolumn{5}{|l|}{ Gender } \\
\hline Male & 82 & $42(86 \%)$ & $40(73 \%)$ & \\
\hline Female & 22 & $7(14 \%)$ & $15(27 \%)$ & 0.1489 \\
\hline \multicolumn{5}{|l|}{ Age (years) } \\
\hline Mean & $66($ range $=28-85)$ & & & \\
\hline$<65$ & 45 & $21(43 \%)$ & $24(44 \%)$ & \\
\hline$\geq 65$ & 59 & $28(57 \%)$ & $31(56 \%)$ & 1,0000 \\
\hline \multicolumn{5}{|l|}{ Siewert classification } \\
\hline I & 12 & $3(6 \%)$ & $9(16 \%)$ & \\
\hline II & 60 & $30(61 \%)$ & $30(55 \%)$ & \\
\hline III & 32 & $16(33 \%)$ & $16(29 \%)$ & 0.2641 \\
\hline \multicolumn{5}{|c|}{ Histopathological grading } \\
\hline Differentiated & 57 & $31(63 \%)$ & $26(47 \%)$ & \\
\hline Undifferentiated & 47 & $18(37 \%)$ & $29(53 \%)$ & 0.1175 \\
\hline \multicolumn{5}{|l|}{ Tumor size (mm) } \\
\hline$<40$ & 39 & $16(33 \%)$ & $23(42 \%)$ & \\
\hline$\geq 40$ & 65 & $33(67 \%)$ & $32(58 \%)$ & 0.4179 \\
\hline \multicolumn{5}{|l|}{ Venous invasion } \\
\hline 0 & 49 & $15(31 \%)$ & $34(62 \%)$ & \\
\hline 1 & 29 & $13(27 \%)$ & $16(29 \%)$ & \\
\hline 2 & 13 & $9(18 \%)$ & $4(7 \%)$ & \\
\hline 3 & 13 & $12(24 \%)$ & $1(2 \%)$ & 0.0003 \\
\hline \multicolumn{5}{|l|}{ Lymphatic invasion } \\
\hline 0 & 41 & $13(27 \%)$ & $28(51 \%)$ & \\
\hline 1 & 32 & $15(31 \%)$ & $17(31 \%)$ & \\
\hline 2 & 11 & $5(10 \%)$ & $6(11 \%)$ & \\
\hline 3 & 20 & $16(33 \%)$ & $4(7 \%)$ & 0.0056 \\
\hline \multicolumn{5}{|l|}{ TNM classification } \\
\hline \multicolumn{5}{|l|}{ pT category } \\
\hline $\mathrm{T} 1$ & 31 & $4(8 \%)$ & $27(49 \%)$ & \\
\hline $\mathrm{T} 2$ & 15 & $8(16 \%)$ & $7(13 \%)$ & \\
\hline $\mathrm{T} 3$ & 29 & $17(35 \%)$ & $12(22 \%)$ & \\
\hline $\mathrm{T} 4$ & 29 & $20(41 \%)$ & $9(16 \%)$ & $<0.0001$ \\
\hline \multicolumn{5}{|l|}{ pN category } \\
\hline No & 55 & $18(37 \%)$ & $37(67 \%)$ & \\
\hline N1 & 9 & $4(8 \%)$ & $5(9 \%)$ & \\
\hline $\mathrm{N} 2$ & 16 & $8(16 \%)$ & $8(15 \%)$ & 0.0023 \\
\hline N3 & 24 & $19(39 \%)$ & $5(9 \%)$ & \\
\hline \multicolumn{5}{|l|}{ pStage } \\
\hline I & 37 & $7(14 \%)$ & $30(55 \%)$ & \\
\hline II & 17 & $10(20 \%)$ & $7(13 \%)$ & \\
\hline III & 50 & $32(65 \%)$ & $18(33 \%)$ & $<0.0001$ \\
\hline \multicolumn{5}{|l|}{ Recurrence } \\
\hline Yes & 69 & $21(43 \%)$ & $13(24 \%)$ & \\
\hline No & 35 & $28(57 \%)$ & $42(76 \%)$ & 0.0587 \\
\hline
\end{tabular}

Statistically significant values are shown in bold. *Chi-squared or Fisher's exact test.

Association between EGFR protein levels and clinicopathological characteristics in primary AEG. The relationship between the expression of the EGFR protein and clinicopathological characteristics is summarized in Table I.
The protein expression of EGFR was significantly associated with more aggressive venous $(p=0.0003)$ and lymphatic invasion $(p=0.0056)$, deeper depth of invasion $(p<0.0001)$, and higher rates of lymph node metastasis $(p=0.0023)$, 
Table II. Univariate and multivariate analysis.

\begin{tabular}{|c|c|c|c|c|c|}
\hline \multirow[t]{2}{*}{ Variable } & & \multirow{2}{*}{$\frac{\text { Univariate }^{\mathrm{a}}}{p \text {-Value }}$} & \multicolumn{3}{|c|}{ Multivariate ${ }^{\mathrm{b}}$} \\
\hline & & & HR & $95 \% \mathrm{CI}$ & $p$-Value \\
\hline Gender & Male versus female & 0.8606 & & - & \\
\hline Age & $\geq 65$ versus $<65$ years & 0.5975 & & - & \\
\hline Siewert classification & 1 versus $11-111$ & 0.2602 & & - & \\
\hline Histological type & Undifferentiated versus differentiated & 0.0816 & 2.165 & $1.052-4.566$ & 0.0358 \\
\hline Tumor size & $\geq 40$ versus $<40 \mathrm{~mm}$ & 0.0502 & & - & \\
\hline Venous invasion & Positive versus negative & $<0.0001$ & 3.787 & $1.680-9.740$ & 0.0009 \\
\hline Lymphatic invasion & Positive versus negative & $<0.0001$ & & - & \\
\hline pT-stage & $\mathrm{T} 3-4$ versus $\mathrm{T} 1-2$ & $<0.0001$ & & - & \\
\hline pN-stage & N1-3 versus N0 & $<0.0001$ & 2.742 & $1.227-6.796$ & 0.0130 \\
\hline EGFR expression & High versus low & 0.0035 & 2.048 & $1.034-4.254$ & 0.0397 \\
\hline
\end{tabular}

aKaplan and Meier method; statistical significance was determined by log-rank test. bMultivariate survival analysis was performed using Cox's proportional hazard model. HR: Hazard ratio; CI: confidence interval.

whereas other characteristics, including the Siewert classification and histological grade, were not.

In the Cox proportional hazard regression model (Table II), univariate analyses demonstrated that EGFR protein expression, venous invasion, lymphatic invasion, pT category, and $\mathrm{pN}$ category were significantly associated with overall survival. When the data were stratified for multivariate analysis using the Cox proportional hazards analysis procedures, EGFR immunoreactivity in tumor cells remained significant (hazard $\operatorname{ratiol}(\mathrm{HR})=2.048,95 \%$ $\mathrm{CI}=1.034-4.254 ; p=0.0397)$ for overall survival for the whole patient cohort, suggesting that EGFR immunoreactivity can be an independent predictor of overall survival.

\section{Discussion}

The present study retrospectively evaluated the influence of EGFR overexpression on the outcomes of patients with AEG. Our data show that EGFR expression is strongly correlated with poor overall and disease-free survival in univariate analyses and an independent predictor of overall survival in multivariate analyses. As far as we are aware of, this is the first study to show that EGFR status correlates significantly with poor outcome in patients with AEG. These results suggest that EGFR could be an important molecular marker for predicting the malignant properties of AEG and also a target for molecular therapy.

In patients with head and neck, ovarian, cervical, bladder, and esophageal squamous cell carcinomas, EGFR expression is a strong prognostic indicator that correlates with both higher recurrence rates and shorter survival. Regarding gastric cancer, EGFR overexpression is also significantly associated with a worse outcome after curative resection of stage II/III gastric cancer (28); however, previous studies of the prognostic role of EGFR in esophageal adenocarcinomas or AEG have been limited (32-36). Wang et al. reported that overexpression of EGFR in esophageal adenocarcinoma and AEG relates to poor outcomes (36). However, EGFR overexpression was not an independent prognostic factor. In the current study, we investigated only patients with AEG restricted to the Siewert definition and, thereby, demonstrated that EGFR positivity was independently associated with a worse outcome in the multivariate analysis.

EGFR is a trans-membrane glycoprotein receptor for the EGF family of extracellular protein ligands (37) and is overexpressed in several malignancies. Ligand binding to the extracellular domain leads to EGFR activation and phosphorylation of the intracellular tyrosine kinase, which then directs activation of the rat sarcoma (RAS)/rapidly accelerated fibrosarcoma (RAF)/mitogen-activated protein kinase (MAPK) or the protein kinase B (AKT)/mammalian target of rapamycin (MTOR) pathway (38-40). EGFR overexpression occurred in $30-50 \%$ of AEG in previous reports (36), and the frequency in our present study is similar to this value.

Regarding the effect of EGFR inhibitors in gastric cancer or AEG, the phase III trial EXPAND (erbitux in combination with xeloda and cisplatin in advanced gastric or esophagogastric junction cancer) randomized 904 patients to cisplatin with capecitabine with or without cetuximab. No PFS or OS benefit for the cetuximab-treated group was found (41). Panitumumab is the first fully human $\operatorname{IgG} 2$ monoclonal antibody targeting EGFR. The REAL-3 study did not show any benefit at preplanned interim analysis and was stopped early (42). Gefitinib is an oral EGFR tyrosine kinase inhibitor (TKI). A phase III trial (NCT01243398) randomized patients with advanced AEG to gefitinib versus 
placebo after progression on chemotherapy. The study was completed and the pending results will help better delineate the activity of gefitinib (43). Erlotinib is another oral EGFR TKI, which was found to be active in patients with AEG cancer with a response rate of $9 \%$, but with no responses in gastric cancer (44). Thus, EGFR-targeted agents have produced only modest success in AEG and gastric cancer. However, our present study indicates that EGFR overexpression could be a strong indicator for prognosis in AEG. Further studies may be warranted to better understand the role of EGFR receptor signaling in AEG and to develop novel EGFR-targeted agents for AEG.

\section{Conflicts of Interest}

All Authors have no conflict of interest to declare in regard to this study.

\section{References}

1 Devesa SS, Blot WJ and Fraumeni JF Jr.: Changing patterns in the incidence of esophageal and gastric carcinoma in the United States. Cancer 83: 2049-2053, 1998.

2 Kusano C, Gotoda T, Khor CJ, Katai H, Kato H, Taniguchi H and Shimoda T: Changing trends in the proportion of adenocarcinoma of the esophagogastric junction in a large tertiary referral center in Japan. J Gastroenterol Hepatol 23: 1662-1665, 2008.

3 Fang WL, Wu CW, Chen JH, Lo SS, Hsieh MC, Shen KH, Hsu WH, Li AF and Lui WY: Esophagogastric junction adenocarcinoma according to Siewert classification in Taiwan. Ann Surg Oncol 16: 3237-3244, 2009.

4 Hosokawa Y, Kinoshita T, Konishi M, Takahashi S, Gotohda N, Kato Y, Daiko H, Nishimura M, Katsumata K, Sugiyama Y and Kinoshita T: Clinicopathological features and prognostic factors of adenocarcinoma of the esophagogastric junction according to Siewert classification: experiences at a single institution in Japan. Ann Surg Oncol 19: 677-683, 2012.

5 Hur C, Miller M, Kong CY, Dowling EC, Nattinger KJ, Dunn $\mathrm{M}$ and Feuer EJ: Trends in esophageal adenocarcinoma incidence and mortality. Cancer 119: 1149-1158, 2013.

6 Cen P, Banki F, Cheng L, Khalil K, Du XL, Fallon M, Amato RJ and Kaiser LR: Changes in age, stage distribution and survival of patients with esophageal adenocarcinoma over three decades in the United States. Ann Surg Oncol 19: 1685-1691, 2012.

7 Franklin WA, Veve R, Hirsch FR, Helfrich BA and Bunn PA, Jr.: Epidermal growth factor receptor family in lung cancer and premalignancy. Semin Oncol 29: 3-14, 2002.

8 Bang YJ, Van Cutsem E, Feyereislova A, Chung HC, Shen L, Sawaki A, Lordick F, Ohtsu A, Omuro Y, Satoh T, Aprile G, Kulikov E, Hill J, Lehle M, Ruschoff J, Kang YK and To GATI: Trastuzumab in combination with chemotherapy versus chemotherapy alone for treatment of HER2-positive advanced gastric or gastro-oesophageal junction cancer (ToGA): a phase 3, open-label, randomised controlled trial. Lancet 376: 687-697, 2010.

9 Ono Y, Nakanishi Y, Ino Y, Niki T, Yamada T, Yoshimura K, Saikawa M, Nakajima T and Hirohashi S: Clinocopathologic significance of laminin-5 gamma2 chain expression in squamous cell carcinoma of the tongue: immunohistochemical analysis of 67 lesions. Cancer 85: 2315-2321, 1999.

10 Ishitoya J, Toriyama M, Oguchi N, Kitamura K, Ohshima M, Asano $\mathrm{K}$ and Yamamoto $\mathrm{T}$ : Gene amplification and overexpression of EGF receptor in squamous cell carcinomas of the head and neck. Br J Cancer 59: 559-562, 1989.

11 Katoh K, Nakanishi Y, Akimoto S, Yoshimura K, Takagi M, Sakamoto $\mathrm{M}$ and Hirohashi S: Correlation between laminin-5 gamma2 chain expression and epidermal growth factor receptor expression and its clinicopathological significance in squamous cell carcinoma of the tongue. Oncology 62: 318-326, 2002.

12 Kanamori A, Abe Y, Yajima Y, Manabe Y and Ito K: Epidermal growth factor receptors in plasma membranes of normal and diseased human thyroid glands. J Clin Endocrinol Metab 68: 899-903, 1989.

13 Hoos A, Urist MJ, Stojadinovic A, Mastorides S, Dudas ME, Leung DH, Kuo D, Brennan MF, Lewis JJ and Cordon-Cardo C: Validation of tissue microarrays for immunohistochemical profiling of cancer specimens using the example of human fibroblastic tumors. Am J Pathol 158: 1245-1251, 2001.

14 Perez EA: The role of adjuvant monoclonal antibody therapy for breast cancer: rationale and new studies. Curr Oncol Rep 3: 516$522,2001$.

15 Ito K, Sasano H, Ozawa N, Sato S, Silverberg SG and Yajima A: Immunolocalization of epidermal growth factor receptor and c-ERBB-2 oncogene product in human ovarian carcinoma. Int J Gynecol Pathol 11: 253-257, 1992.

16 Mayer A, Takimoto M, Fritz E, Schellander G, Kofler K and Ludwig $\mathrm{H}$ : The prognostic significance of proliferating cell nuclear antigen, epidermal growth factor receptor and $M D R$ gene expression in colorectal cancer. Cancer 71: 2454-2460, 1993.

17 Nicholson RI, Gee JM and Harper ME: EGFR and cancer prognosis. Eur J Cancer 37(Suppl 4): S9-15, 2001.

18 Hemming AW, Davis NL, Kluftinger A, Robinson B, Quenville NF, Liseman B and LeRiche J: Prognostic markers of colorectal cancer: an evaluation of DNA content, epidermal growth factor receptor and Ki-67. J Surg Oncol 51: 147-152, 1992.

19 Gibault L, Metges JP, Conan-Charlet V, Lozac'h P, Robaszkiewicz M, Bessaguet C, Lagarde $\mathrm{N}$ and Volant A: Diffuse EGFR staining is associated with reduced overall survival in locally advanced oesophageal squamous cell cancer. Br J Cancer 93: 107-115, 2005.

20 Neal DE, Marsh C, Bennett MK, Abel PD, Hall RR, Sainsbury JR and Harris AL: Epidermal-growth-factor receptors in human bladder cancer: comparison of invasive and superficial tumours. Lancet 1: 366-368, 1985.

21 Veale D, Kerr N, Gibson GJ, Kelly PJ and Harris AL: The relationship of quantitative epidermal growth factor receptor expression in non-small cell lung cancer to long term survival. Br J Cancer 68: 162-165, 1993.

22 Yano H, Shiozaki H, Kobayashi K, Yano T, Tahara H, Tamura S and Mori $\mathrm{T}$ : Immunohistologic detection of the epidermal growth factor receptor in human esophageal squamous cell carcinoma. Cancer 67: 91-98, 1991.

23 Itakura Y, Sasano H, Shiga C, Furukawa Y, Shiga K, Mori S and Nagura H: Epidermal growth factor receptor overexpression in esophageal carcinoma. An immunohistochemical study correlated with clinicopathologic findings and DNA amplification. Cancer 74: 795-804, 1994. 
24 Garcia I, Vizoso F, Martin A, Sanz L, Abdel-Lah O, Raigoso P and Garcia-Muniz JL: Clinical significance of the epidermal growth factor receptor and HER2 receptor in resectable gastric cancer. Ann Surg Oncol 10: 234-241, 2003.

25 Hayashi M, Inokuchi M, Takagi Y, Yamada H, Kojima K, Kumagai J, Kawano T and Sugihara K: High expression of HER3 is associated with a decreased survival in gastric cancer. Clin Cancer Res 14: 7843-7849, 2008.

26 Kim MA, Lee HS, Lee HE, Jeon YK, Yang HK and Kim WH: EGFR in gastric carcinomas: prognostic significance of protein overexpression and high gene copy number. Histopathology 52: 738-746, 2008.

27 Yasui W, Hata J, Yokozaki H, Nakatani H, Ochiai A, Ito H and Tahara E: Interaction between epidermal growth factor and its receptor in progression of human gastric carcinoma. Int $\mathrm{J}$ Cancer 41: 211-217, 1988.

28 Terashima M, Kitada K, Ochiai A, Ichikawa W, Kurahashi I, Sakuramoto S, Katai H, Sano T, Imamura H, Sasako M; for the ACTS-GC Group: Impact of expression of human epidermal growth factor receptors EGFR and ERBB2 on survival in stage II/III gastric cancer. Clin Cancer Res 18: 5992-6000, 2012.

29 Sobin LH and Compton CC: TNM seventh edition: What's new, what's changed: communication from the International Union Against Cancer and the American Joint Committee on Cancer. Cancer 116: 5336-5339, 2010.

30 Tsuda H: Individualization of breast cancer based on histopathological features and molecular alterations. Breast Cancer 15: 121-132, 2008.

31 Kobayashi H, Komatsu S, Ichikawa D, Kawaguchi T, Hirajima S, Miyamae M, Okajima W, Ohashi T, Kosuga T, Konishi H, Shiozaki A, Fujiwara H, Okamoto K, Tsuda H and Otsuji E: Overexpression of denticle-less E3 ubiquitin protein ligase homolog (DTL) is related to poor outcome in gastric carcinoma. Oncotarget 6: 36615-36624, 2015.

32 Yacoub L, Goldman H and Odze RD: Transforming growth factor-alpha, epidermal growth factor receptor and $\mathrm{MiB}-1$ expression in Barrett's-associated neoplasia: correlation with prognosis. Mod Pathol 10: 105-112, 1997.

33 Aloia TA, Harpole DH Jr., Reed CE, Allegra C, Moore MB, Herndon JE, 2nd and D'Amico TA: Tumor marker expression is predictive of survival in patients with esophageal cancer. Ann Thorac Surg 72: 859-866, 2001

34 Gibson MK, Abraham SC, Wu TT, Burtness B, Heitmiller RF, Heath $\mathrm{E}$ and Forastiere A: Epidermal growth factor receptor, $p 53$ mutation and pathological response predict survival in patients with locally advanced esophageal cancer treated with preoperative chemoradiotherapy. Clin Cancer Res 9: 6461-6468, 2003.

35 Wilkinson NW, Black JD, Roukhadze E, Driscoll D, Smiley S, Hoshi H, Geradts J, Javle M and Brattain M: Epidermal growth factor receptor expression correlates with histologic grade in resected esophageal adenocarcinoma. J Gastrointest Surg 8: 448453, 2004.

36 Wang KL, Wu TT, Choi IS, Wang H, Resetkova E, Correa AM, Hofstetter WL, Swisher SG, Ajani JA, Rashid A and Albarracin CT: Expression of epidermal growth factor receptor in esophageal and esophagogastric junction adenocarcinomas: association with poor outcome. Cancer 109: 658-667, 2007.
37 Herbst RS: Review of epidermal growth factor receptor biology. Int J Radiat Oncol Biol Phys 59: 21-26, 2004.

38 Oda K, Matsuoka Y, Funahashi A and Kitano H: A comprehensive pathway map of epidermal growth factor receptor signaling. Mol Syst Biol 1: 2005.0010, 2005.

39 Galizia G, Lieto E, Orditura M, Castellano P, Mura AL, Imperatore V, Pinto M, Zamboli A, De Vita F and Ferraraccio F: Epidermal growth factor receptor (EGFR) expression is associated with a worse prognosis in gastric cancer patients undergoing curative surgery. World J Surg 31: 1458-1468, 2007.

40 Lieto E, Ferraraccio F, Orditura M, Castellano P, Mura AL, Pinto M, Zamboli A, De Vita F and Galizia G: Expression of vascular endothelial growth factor (VEGF) and epidermal growth factor receptor (EGFR) is an independent prognostic indicator of worse outcome in gastric cancer patients. Ann Surg Oncol 15: 69-79, 2008.

41 Lordick F, Kang YK, Chung HC, Salman P, Oh SC, Bodoky G, Kurteva G, Volovat C, Moiseyenko VM, Gorbunova V, Park JO, Sawaki A, Celik I, Gotte H, Melezinkova H, Moehler M, on behalf of the Arbeitsgemeinschaft Internistische Onkologie (AIO) and EXPAND Investigators: Capecitabine and cisplatin with or without cetuximab for patients with previously untreated advanced gastric cancer (EXPAND): a randomised, open-label phase 3 trial. Lancet Oncol 14: 490-499, 2013.

42 Waddell T, Chau I, Cunningham D, Gonzalez D, Okines AF, Okines C, Wotherspoon A, Saffery C, Middleton G, Wadsley J, Ferry D, Mansoor W, Crosby T, Coxon F, Smith D, Waters J, Iveson T, Falk S, Slater S, Peckitt $\mathrm{C}$ and Barbachano Y: Epirubicin, oxaliplatin and capecitabine with or without panitumumab for patients with previously untreated advanced oesophagogastric cancer (REAL3): a randomised, open-label phase 3 trial. Lancet Oncol 14: 481-489, 2013.

43 Dutton SJ, Ferry DR, Blazeby JM, Abbas H, Dahle-Smith A, Mansoor W, Thompson J, Harrison M, Chatterjee A, Falk S, Garcia-Alonso A, Fyfe DW, Hubner RA, Gamble T, Peachey L, Davoudianfar M, Pearson SR, Julier P, Jankowski J, Kerr R and Petty RD: Gefitinib for oesophageal cancer progressing after chemotherapy (COG): a phase 3, multicentre, double-blind, placebo-controlled randomised trial. Lancet Oncol 15: 894-904, 2014.

44 Dragovich T, McCoy S, Fenoglio-Preiser CM, Wang J, Benedetti JK, Baker AF, Hackett CB, Urba SG, Zaner KS, Blanke CD and Abbruzzese JL: Phase II trial of erlotinib in gastroesophageal junction and gastric adenocarcinomas: SWOG 0127. J Clin Oncol 24: 4922-4927, 2006. 